Has any one, in the discussion of Mallet's hypothesis, thought of bringing its probability to such a test as the volatilisation of the hydrocarbons of coal-beds in a highly plicated region like Belgium?

It is a remarkable fact, and one which seems to me inconsistent with the mechanical theory of earth-heat, that of two extensive regions, Belgium and Eastern Pennsylvania, equally and excessively disturbed by complications, all the coal-beds of the one are anthracite, and all those of the other are bituminous.

Again, of two regions equally undisturbed, Western Pennsylvania and Arkansas, the horizontal coal-beds of the one are bituminous and of the other anthracite.

Surely, if movements of stratum on stratum produce all the needful heat, no plicated coal-beds should escape being converted to antbracite; and I should much like to hear from English geologists how this argument is to be met. My own explanation of the origin of anthracite is not worth much, but it is the best I know. I refer such origin to three causes acting in conjunc. tion-(I) Heat due to superposed (now wholly or partially re. moved) Permian and later formations; (2) Greater proportion of sands in the anthracite and of clays in the bituminous coalmeasures; and (3) Plication and fracture, permitting the exit of volatilised hydrocarbons into the atmosphere.

American Philosophical Society, Philadelphia, May 22

\section{Evolution Old and New}

Mr. A. R. WALlace writes, in Nature, vol. xx. p. I43, that, according to the theory which I support, Australian (and more especially Queensland) sheep should show a tendency to grow a scantier and thinner fleece than their English ancestors. "If Mr. Butler," he continues, "could adduce on good authority such a fact as this, he would have some evidence in his favour, instead of which he can only make suppositions."

I never was in Australia, but had some years' experience of sheep-farming in New Zealand. It was generally believed, in my time, that fleeces soon became short and hairy in Queensland, and even in the more northern part of New South Wales. You must, however, have many readers who could tell us what the facts are. May I hope that you will kindly insert this, so as to get the matter settled by eliciting information from a competent authority? I am speaking, of course, of sheep that are left to the effect of the climate, without being frequently crossed with rams from colder countries. Do the fleeces of such sheep deteriorate in Queensland?

S. BUTLER

June 12

\section{The River Elbe}

IN NATURE, vol. xiv. p. 498 , some particulars are given of measurements made in $187 \mathrm{I}$ and 1872 of the water flowing past in the Elbe at the boundary between Saxony and Bohemia. The river basin in Bohemia above this point is stated at 880 square miles, which is evidently wrong, as the annual discharge of 6 , I $79,000,000$ cubic metres ( $218,223,743,000$ cubic feet) would give a depth of $107^{-64}$ inches run off the ground. Measuring roughly on the map, the area of Bohemia-which, apparently, all drains into the Elbe-is 20,000 English square miles. If, on the other hand, the measurements of the river water and the solids in solution and suspension are correctly given, and the river basin is 20,000 square miles, the rainfall must have been exceptionally low at the time the measurements were taken, as the figures represent only about half that of the mean annual flow off the ground in the Danube basin, which is $9^{\circ} 06$ inches. Perhaps the writer of the notice will be able to find out how these discrepancies occur. I may add that, taking the figures as given in NATURE, 607 tons per square mile per annum are removed in solution in the Elbe water. From a district com. posed mostly of silurian rocks, this is manifestly absurd. According to my calculations, ${ }^{1} 72^{\prime} 7$ tons per square mile are annually removed in solution in the Danuber square

Blindellsands, June i 7

\section{T. Mellard ReAde}

\section{Electric Light}

IN NATURE, vol. xx. p. IIO, an account is given of Sir William Thomson's evidence on the electric light. It is stated "that one horse-power had produced $\mathbf{I}, 200$ candles of actual r "Geological Time," Proceedings of Liverpocl Geological Society, Session
$\times 876-7$. visible electric light, whereas one horse-power of energy would only produce 12-candle gas-light." In the report of Sir J. W. Bazalgette and Mr. Keates to the Board of Works, which is probably the best report we have yet had on the subject, as to the actual cost of the electric light on the Thames Embankment, it is stated that the cost of the electric light was $5{ }^{\circ} 75^{d}$. per hour, whereas the cost of the gas required to produce a light equal to the electric light as regards illuminating power, in an opal globe, was $2.00 d$, and in a frosted globe $3.50 d$. per hour. Would any of your numerous readers be kind enough to give me some idea of the qualifications to be appended to the above statements, which will reduce the long odds calculated by Thomson of $I 00$ to $I$ in favour of the electric light, to the odds of 2 to $I$ against it as found in actual practice? In conclusion may I venture humbly to suggest that such conflicting statements as the above, if unexplained, are apt to bring the dicta of scientific men into disrepute with the thinking portion of the general pablic.

F. J. M. P.

\section{The Climbing Perch}

THE aquarium of the Zoological Society's Gardens in Regent's Park has lately received a contribution of five specimens of the "Climbing Perch" (Anabas scandens). They were very kindly obtained for me by my friend, Mr. A. Ferguson, of Colombo, Ceylon, and were brought home in excellent condition by my brother, Mr. A. F. Dobson. Mr. Ferguson (who is so well known in Ceylon as a naturalist of great experience) kept the fish for some months in an aquarium, and trained them to take chopped meat from the hand, so that they were in the best possible condition for their long journey.

The first specimens of this fish which arrived alive in Europe were sent by me from Calcutta in 1872 to the Royal Zoological Gardens in the Phonix Park in Dublin, where they lived for a considerable time.

I have described (P. Z. S., I874), in my paper "On the Respiration of Indian Fresh-water Fishes" the manner in which Anabas scandens takes in, and rejects again, the atmospheric air, and on a visit to the aquarium in the Gardens the peculiar conduct of these fishes when respiring may be witnessed by any one.

Mr. Ferguson informs me that he has specimens of some species of Ophiocephali and the remarkable Arizus bakeri, which carries its young in its mouth, in training, and I hope soon to have an opportunity of having them safely carried to England.

Netley, June 14

G. E. DOBSON

\section{Oxygenated Rain}

ON Thursday, June 12, at half-past eleven in the morning, $x$ remarkable shower of rain fell over. London, which might almost be described as " effervescing ;" the drops whilst falling appeared to be colourless and perfectly transparent, but on striking against any solid surface they became milky, and on close examination it was evident that this cloudy appearance was caused by a number of very minute air-bubbles, which rapidly increased in size, and then burst. From the bleaching power which this rain. appeared to have, I am led to believe that there was nascent oxygen in the gas thus evolved. Those who traverse the streets of London in the early morning may now and then observe the red colour of all bright iron-work in the pavement, such as coalplates, \&c., due to the oxidising influence of a thunder-shower in the night; this effect does not follow every thunder-shower, but seems to indicate a peculiar atmospheric condition. Have any memoranda on this subject been recorded?

EDWARD SOLLY

\section{WILLIAM FROUDE I}

AST week we called attention to Mr. Froude's discoveries of those laws of motion of floating bodies, upon which the behaviour and safety of a ship passively floating among sea waves depends. We now purpose giving a brief outline of his researches in another branch of hydrodynamics by which he arrived at a true appreciation of the nature and amount of the resistance opposed by water to the passage of a body like a ship through it. In connection with the resistance of ships, the subject of marine propulsion, which Mr. Froude bas also done much 